\title{
KEBERMAKNAAN HIDUP ANAK JALANAN PEREMPUAN YANG MEMILIKI ANAK ATAS KEHAMILAN YANG TIDAK DIKEHENDAKI
}

\author{
Dessy Pranungsari ${ }^{1}$, Fatwa Tentama ${ }^{2}$ \\ Fakultas Psikologi, Universitas Ahmad Dahlan, \\ Jl. Kapas No. 9, Semaki, Umbulharjo, Yogyakarta 55166 \\ ${ }^{1}$ dessyuad@gmail.com, ${ }^{2}$ fatwa.tentama@psy.uad.ac.id
}

\begin{abstract}
This study aimed to describe the process and the characteristics of the meaningfulness of life of street girls who have been sexually abused after having children from unwanted pregnancies. Subjects consisted of two female street children under the age of 18 years who were victims of sexual violence, have children from unwanted pregnancies and lived in the city of Yogyakarta. A non-participant observation and interviews were employed for data collection, while interview with significant person of the two subjects was conducted as atriangulation of the data. Analysis of the data was performed using content analysis. The results showed that a meaningfulness of life of subject 1 was obtained after having a child at which she became more vibrant in life and she hope that she will see her son grow up well. She also finds a better and more mature life by becoming a mother. Meanwhile, the meaningfulness of life of subject 2 acquired after experiencing a difficult childbirth process that insightfully led her to reflect on how her mother had been hardly struggle to raise her up and she deeply regret that in fact she had not been able to make her mother happy until her mother passed away.
\end{abstract}

Keywords: meaningfulness of life, street girl, unwanted pregnancy

\begin{abstract}
Abstrak
Penelitian ini bertujuan untuk mendeskripsikan proses dan ciri-ciri kebermaknaan hidup anak jalanan perempuan korban kekerasan seksual setelah memiliki anak dari kehamilan yang tidak dikehendaki. Subjek terdiri dari dua anak jalanan perempuan berusia di bawah 18 tahun, merupakan korban kekerasan seksual, memiliki anak dari kehamilan yang tidak dikehendaki, memiliki anak sebelum usia 18 tahun, dan bertempat tinggal di kota Yogyakarta. Penelitian ini menggunakan metode kualitatif dengan pendekatan studi kasus. Pengumpulan data menggunakan observasi non partisipan dan wawancara terhadap subjek dan significant person sebagai triangulasi data. Analisis hasil menggunakan analisis isi dengan tahap organisasi data secara sistematis, koding dan analisis, pengujian terhadap dugaan, strategi analisis, dan interpretasi. Hasil penelitian menunjukkan kebermaknaan hidup subjek 1 didapatkannya setelah memiliki anak, subjek menjadi lebih bersemangat dalam hidup karena memiliki harapan untuk dapat melihat anaknya tumbuh dengan baik dan merasa hidupnya lebih baik setelah memiliki anak, termasuk menjadi pribadi yang lebih dewasa. Kebermaknaan hidup subjek 2 didapatkannya saat proses persalinan karena perjuangan proses persalinan yang
\end{abstract}


berat dan juga perjuangan dalam mengurus anak membuatnya menyesal karena subjek tidak dapat menjadi anak yang baik sampai ibunya meninggal dunia. Keinginan yang kuat agar anaknya menjadi anak yang baik dan patuh kepada orang tua, menjadikannya pribadi yang lebih baik.

Kata kunci: anak jalanan perempuan, kebermaknaan hidup, kehamilan tidak dikendaki

\section{Pendahuluan}

Anak jalanan dengan berbagai konflik dan stigma yang melekat di masyarakat, membuat anak jalanan menjadi sosok yang terus menjadi bahan diskusi dengan permasalahan yang sulit dipecahkan. Masalah yang saat ini masih menjadi perhatian berbagai pihak adalah mengenai kekerasan yang dialami anak jalanan khususnya anak jalanan perempuan. Berbagai resiko yang mengancam anak jalanan perempuan antara lain traficking, pelacuran, perkosaan, pelecehan seksual, kehamilan yang tidak diinginkan, penyakit menular seksual, dan berbagai persoalan psikososial lainnya. Safaraz dan Riaz (2014) dalam penelitiannya menyebutkan bahwa meskipun perkembangan ekonomi dan urbanisasi yang pesat dengan kebebasan dan kesetaraan, namun anak jalanan perempuan masih kehilangan hak dan tereksploitasi pada berbagai tahap kehidupan. Ketidakberdayaan karena buta huruf dan tidak adanya ketrampilan menjadikan anak jalanan semakin sulit untuk mendapatkan kehormatan sebagai perempuan.

Menurut Little dan Hamby (1999) meneliti tentang kekerasan seksual anak adalah sesuatu yang menantang sekaligus penuh dengan tuntutan. Sesuai dengan Undang Undang Perlindungan Anak No 35 tahun 2014 yang menyatakan bahwa Kekerasan adalah setiap perbuatan terhadap Anak (dibawah 18 tahun) yang berakibat timbulnya kesengsaraan atau penderitaan secara fisik, psikis, seksual, dan/atau penelantaran, termasuk ancaman untuk melakukan perbuatan, pemaksaan, atau perampasan kemerdekaan.

Anak jalanan perempuan merupakan pihak yang dianggap paling rentan mengalami kekerasan seksual di jalanan, mengingat posisi anak dan perempuan yang melekat padanya menjadikan anak jalanan perempuan dianggap lemah dan tak berdaya. Menurut Paolucci, Genuis dan Violato (2001) gender berhubungan dengan dampak kekerasan seksual. Gaya pergaulan remaja di komunitas anak jalanan yang sangat bebas ini menjadikan anak jalanan perempuan rentan mengalami kekerasan seksual yang seringkali berdampak pada kehamilan yang tidak dikehendaki di usia muda.

Kekerasan seksual yang terjadi pada anak jalanan yaitu kekerasan yang menyangkut pemaksaan demi pelampiasan nafsu seksual. Selain perkosaan, bentukbentuk kekerasan juga termasuk perilaku merusak organ reproduksi perempuan, dan pelecehan (meraba payudara, menggesek-gesekkan alat kelamin) dan juga eksploitasi seksual komersial (Triono, 2007). Tingginya tingkat kekerasan seksual terutama pelecehan seksual banyak ditemukan di kalangan remaja tunawisma yang melarikan diri (Rew Johnson, \& Kauzekanani, 2006).

Hasil dokumentasi Komisi Nasional Perempuan sejak tahun 1998 hingga 2010 menunjukkan bahwa hampir sepertiga kasus kekerasan terhadap perempuan adalah kasus kekerasan seksual, atau ada 91.311 kasus kekerasan seksual dari 295.836 total kasus kekerasan terhadap perempuan (Komnas Perempuan, 2010). Kasus kekerasan 
seksual dalam pacaran selalu meningkat setiap tahunnya dan memiliki dampak negatif yang dapat menimbulkan konsekuensi yang panjang dalam hidup remaja. Kekerasan seksual anak merupakan sesuatu yang disembunyikan sebab mengandung kerahasiaan (Alaggia, 2004) sehingga seringkali tidak menemukan penyelesaian.

Kekerasan seksual menurut Yantzi (2009) adalah suatu bentuk kekerasan yang terjadi karena persoalan seksualitas. Kekerasan seksual sebagai perilaku yang dilakukan melalui pendekatan-pendekatan yang terkait dengan seks yang tidak diinginkan, termasuk permintaan untuk melakukan hubungan seks, dan perilaku lainnya yang secara verbal ataupun fisik merujuk pada aktivitas seksual (Sorenson, 1997). Pada umumnya korban adalah anak-anak dan remaja, namun tidak menutup kemungkinan bahwa keduanya (korban dan pelaku adalah anak-anak).

Kekerasan seksual terhadap perempuan menurut Komnas Perempuan (2010) dimaknai sebagai: sebuah pelanggaran hak asasi manusia yang berakar pada diskriminasi berbasis gender, tindakan seksual, percobaan untuk mendapatkan tindakan seksual, ucapan yang menyasar seksual, tindakan untuk memperdagangkan, tindakan yang menyasar seksualitas seseorang yang dilakukan dengan paksaan, intimidasi, ancaman, penahanan, tekanan psikologis, penyalahgunaan kekuasaan, mengambil kesempatan dari lingkungan yang koersif, atau atas seseorang yang tidak mampu memberikan persetujuan yang sesungguhnya. Tindakan yang bersifat seksual itu tidak terbatas pada serangan fisik kepada tubuh seseorang dan dapat termasuk tindakantindakan yang tidak melibatkan penetrasi ataupun kontak fisik.

Menurut teori Piaget (Hurlock, 2005), perkembangan kognitif masa remaja awal berada pada tahap operasional formal (11 tahun-dewasa). Tahap ini adalah puncak individu mencapai kemampuan untuk berfikir sistematis terhadap hal-hal yang abstrak. Kemampuan berfikir sistematis ini menjadi sebuah kemampuan yang diharapkan dapat berkembang secara baik pada anak jalanan perempuan yang mengalami kekerasan untuk bangkit dari keterpurukan dan menemukan makna hidup. Umumnya anak jalanan perempuan memiliki cara pikir yang irasional dengan menyalahkan diri sendiri bahwa adanya peristiwa kekerasan seksual ini adalah salah dirinya dan bukan salah pelaku (Ferrara, 2002).

Bastaman (2007) menyatakan bahwa makna hidup merupakan suatu yang dianggap penting, benar dan didambakan serta memberikan nilai khusus bagi individu. Makna hidup jika berhasil ditemukan dan dipenuhi akan menyebabkan kehidupan terasa bermakna dan berharga yang pada gilirannya akan menimbulkan perasaan bahagia. Kebermaknaan hidup sulit untuk dicari, seperti yang dipaparkan Stegar, Kashdan, Sullivan, \& Lorentz (2008) dalam penelitiannya bahwa orang-orang yang kurang bermakna dalam hidupnya akan mencarinya, namun pencarian makna tidak akan hadir dalam pencarian makna hidup. Kebermaknaan hidup mengandung pengertian seberapa jauh seorang individu dapat mengembangkan dan mengaktualisasikan potensi serta kapasitas yang dimilikinya dan seberapa jauh dirinya telah mencapai tujuan-tujuan hidupnya, dalam rangka memberi makna dalam kehidupannya (Bastaman, 2007).

Anggriany (2006) dalam penelitiannya menyatakan bahwa orang-orang yang mengalami hidup tidak bermakna, mereka merasakan perubahan pada kondisi kehidupan yang lebih bermakna setelah melakukan perubahan dengan melakukan pekerjaan positif dan pengembangan diri (directed activities). Kebermaknaan hidup pada remaja dalam penelitian Rathi dan Rastogi (2007) menunjukkan bahwa perempuan lebih mampu memaknai hidupnya dibandingkan laki-laki. 
Makna hidup adalah hal-hal yang oleh seseorang dipandang penting, dirasakan berharga dan diyakini sebagai sesuatu yang benar serta dapat dijadikan tujuan hidup (Ancok, 2006). Menurut Frankl (Bastaman, 2007) kebermaknaan hidup sebagai keadaan penghayatan hidup yang penuh makna yang membuat individu merasakan hidupnya lebih bahagia, lebih berharga, dan memiliki tujuan yang mulia untuk dipenuhinya.

Menurut Frankl (Triantoro, 2008) manusia dibedakan menjadi dua kelompok yaitu kelompok yang masih mencari dan belum menemukan makna hidupnya dan kelompok yang telah menemukan makna hidupnya melalui sistem nilai pribadi masingmasing. Setiap individu dapat memenuhi makna hidupnya dengan caranya sendiri. Setiap orang akan berbeda-beda dalam menanggapi kehidupnnya sehingga apa yang dianggap bermakna bagi seseorang belum tentu bermakna bagi yang lain.

Adapun ciri-ciri orang yang mampu menemukan makna hidup dan menghayati makna hidup menurut Frank (Schultz, 1991) adalah bebas memilih langkah dan tindakannya sendiri, secara pribadi bertanggungjawab terhadap tingkah laku hidup dan sikap menghadapi nasib tidak ditentukan oleh kekuatan-kekuatan dari luar dirinya. Ciri lain orang yang mampu menemukan makna hidup yaitu telah menemukan arti dalam kehidupan yang sesuai dengan dirinya, secara sadar mengontrol hidupnya, mampu mengungkapkan nilai-nilai daya cipta, nilai-nilai pengalaman dan nilai-nilai sikap, dan telah mengatasi perhatian terhadap dirinya. Orang yang menemukan makna hidup juga berorientasi pada masa depan, mengarahkan dirinya pada tujuan dan tugas-tugas yang akan datang, memiliki alasan untuk meneruskan kehidupan, memiliki komitmen terhadap pekerjaan, mampu memberi dan memerima cinta.

Gambaran tahap-tahap penemuan dan pemenuhan makna hidup dalam penderitaan (Lubis dan Priyanti, 2009) yaitu (1) Tahap derita, tahap derita yaitu pengalaman tragis dan penghayatan hidup tanpa makna. Suatu peristiwa tragis dalam hidup seseorang dapat menimbulkan penghayatan hidup tanpa makna yang ditandai dengan perasaan hampa, gersang, apatis, dan merasa tidak lagi memiliki tujuan hidup serba bosan dan apatis. Kebosanan adalah ketidakmampuan seseorang untuk membangkitkan minat, sedangkan apatis adalah ketidakmampuan seseorang untuk mengambil prakarsa. (2) Tahap penerimaan diri, merupakan tahapan ketika individu mulai menerima apa yang terjadi pada hidupnya, pemahaman diri, dan terjadinya perubahan sikap. Biasanya, munculnya kesadaran ini didorong oleh aneka ragam sebab. Misalnya, karena perenungan diri, konsultasi dengan para ahli, mendapat pandangan dari seseorang, hasil do'a dan ibadah, belajar dari orang lain, dan lain-lain. (3)Tahap penemuan makna hidup, Tahap ini ditandai dengan penyadaran individu akan nilainilai berharga yang sangat penting dalam hidupnya. Hal-hal yang dianggap berharga, dan penting itu mungkin saja berupa nilai-nilai kreatif, nilai-nilai penghayatan, dan nilai-nilai bersikap. (4) Tahap realisasi makna, merupakan tahap keterikatan diri, kegiatan terarah dan pemenuhan makna hidup. Pada tahap ini individu akan mengalami semangat dan gairah dalam hidupnya, kemudian secara sadar melakukan keikatan diri (self commitment) untuk melakukan berbagai kegiatan nyata yang lebih terarah guna memenuhi makna hidupnya.

\section{Metode Penelitian}

Penelitian ini menggunakan metode kualitatif dengan pendekatan studi kasus. Teknik pengambilan sampel yang digunakan dalam penelitian ini adalah purposive 
sampling dengan kriteria: Anak jalanan perempuan usia di bawah 18 tahun, merupakan korban kekerasan seksual memiliki anak dari kehamilan yang tidak dikehendaki. Penelitian dilakukan di Komunitas anak jalanan Yogyakarta dengan jumlah subjek sebanyak 2 orang

Metode pengumpulan data lain yang digunakan adalah teknik wawancara semi terstruktur dan observasi. Wawancara yang dilakukan meliputi pertanyaan seputar kebermaknaan hidup yang meliputi tahap derita dimana subjek mengalami kekerasan seksual sehingga mengalami kehamilan yang tidak dikehendaki, tahap penerimaan diri yang menceritakan mengenai bagaimana subjek menerima kehamilannya, tahap penemuan makna diri dimana subjek mampu menemukan pemaknaan hidup atas derita yang dialaminya, dan tahap realisasi makna yang menjelaskan mengenai harapan dan komitmen subjek mengenai keberadaan anak atas kehamilan yang tidak dikehendaki.

Observasi yang digunakan adalah observasi non-partisipan dengan pencatatan anecdotal record. Observasi dilakukan di setting tempat tinggal subjek dan tempat subjek mengamen. Selama observasi berlangsung kedua subjek selalu mengajak anak dalam kegiatan sehari-hari selama di rumah maupun di jalan. Observasi meliputi observasi secara umum yaitu observasi fisik yang meliputi penampilan subjek dan keadaan lingkungan sekitar subjek, observasi verbal mengenai bagaimana subjek menceritakan pengalaman hidupnya, perilaku dan sikap dalam kehidupan sehari-hari.

Data yang diperoleh dari wawancara dianalisis menggunakan analisis tema dengan pendekatan constant comparative (Poerwandari, 2009). Prosedur analisis data adalah sebagai berikut:

1. Organisasi data secara sistematis.

Data yang diorganisir meliputi data mentah, data yang sudah ditranskrip, memo dan draft insight, dan dokumentasi.

2. Koding dan analisis.

Koding dilakukan dengan langkah peneliti menyusun transkrip verbatim atau catatan lapangan, kemudian secara urut dan kontinyu melakukan penomoran pada baris-baris transkrip dan atau catatan lapangan, kemudian memberikan nama untuk masing-masing berkas.

3. Pengujian terhadap dugaan.

Pengujian terhadap dugaan dilakukan peneliti dengan cara menuliskan pokokpokok pertanyaan penelitian untuk memastikan peneliti tidak melenceng melainkan fokus pada analisis yang sesuai dengan tujuan penelitian, membandingkan tema dan sub tema yang dikembangkan dengan mempelajari kembali sumber data yang ada, dan menggunakan skem atau matriks sederhana untuk mendeskripsikan kesimpulannya.

4. Strategi analisis dan interpretasi.

Strategi analisis yang digunakan adalah dengan menganalisi satu persatu kasus terlebih dahulu, setelah itu peneliti melakukan analisis antar kasus. Hal ini dikarenakan peneliti akan memperoleh gambaran yang mendalam dan komprehensif mengenai isu yang diteliti. Interpretasi yang digunakan meliputi interpretasi yang mengacu pada "pemahaman diri" subjek penelitian, interpretasi "pemahaman umum' masyarakat atau kelompok, dan interpretasi pemahaman teoritis sesuai dengan teori yang digunakan.

5. Keterpercayaan data. 
Dalam penelitian ini, peneliti menggunakan triangulasi data, yakni triangulasi metode (wawancara dan observasi) serta triangulasi data (hasil wawancara dengan subjek dan signifikan personnya) untuk memperoleh data yang valid.

\section{Hasil dan Pembahasan}

Peneliti menemukan berbagai data dan informasi mengenai kebermaknaan hidup subjek penelitian. Data dan informasi tersebut adalah sebagai berikut:

\section{Subjek 1}

Subjek berusia 18 tahun dan memiliki anak yang berusia 2 tahun. Subjek memiliki riwayat keluarga yang kurang harmonis. Subjek anak ke tiga dari Bapak dan Ibu kandungnya, namun sejak subjek masih dalam kandungan, orang tuanya bercerai. Sejak lahir, subjek tinggal bersama ibu dan bapak tirinya, serta kedua adik tirinya. Ibu subjek meninggal beberapa tahun yang lalu. Subjek tetap tinggal bersama bapak tiri dan adik-adiknya. Subjek sempat bertemu dengan Bapak kandungnya, namun justru merasa tidak dekat dengan bapak kandungnya dan merasa canggung untuk tinggal bersama. Subjek pun memilih tinggal bersama bapak tiri yang sudah dianggap seperti bapak kandungnya karena sudah mengasuhnya sejak lahir.

Keluarga subjek tergolong kurang mampu dari segi perekonomian. Bapaknya bekerja sebagai tukang becak dan pemulung, sedangkan ibunya sebagai ibu rumah tangga. Kondisi rumah kontrakan di daerah Kricak, membuat subjek dan adiknya mengenal anak-anak jalanan. Subjek pun memulai mencoba mencari uang di jalan dengan mengemis di perempatan Borobudur Plaza, dekat dengan rumahnya. Subjek sebenarnya tidak diperbolehkan mengemis di jalanan, namun karena keinginan yang tinggi untuk mempunyai uang sendiri dan keinginannya untuk dapat jajan membuat subjek terus mengemis meski harus sembunyi-sembunyi dari orang tua, atau dimarahi selepas pulang ke rumah.

Semakin lama subjek mengenal dunia jalanan, subjek mulai mengamen di bis, agar mendapatkan penghasilan yang lebih besar. Subjek terus bertahan menjadi pengamen, meskipun seringkali mendapat pelecehan seksual dari kernet bis seperti digoda secara verbal maupun dicolek-colek. Kondisi ini sesuai dengan pemaparan Triono (2007) yang menyatakan kekerasan seksual yang terjadi pada anak jalanan yaitu kekerasan yang menyangkut pemaksaan demi pelampiasan nafsu seksual. Selain perkosaan, bentuk-bentuk kekerasan seksual juga termasuk perilaku merusak organ reproduksi perempuan, dan pelecehan (meraba payudara, menggesek-gesekkan alat kelamin) dan juga eksploitasi seksual komersial.

Subjek mengamen setelah pulang sekolah hingga sore hari. Subjek pernah mengalami kecelakaan dan menyebabkan patah kaki dan tidak dapat bersekolah. Subjek awalnya diminta oleh ibunya untuk mengulang sekolah tahun depan bersama dengan adiknya karena kondisi subjek yang tidak dapat berjalan, namun akhirnya subjek justru berhenti sekolah. Setelah kecelakaan, subjek tidak dapat mengamen di bis. Subjek kemudian hanya duduk di perempatan demak ijo untuk kembali mengemis.

Di Demak ijo itulah subjek mengenal San (nama samaran). Subjek kemudian mulai berpacaran dan mengenal kehidupan bebas remaja jalanan. Sampai akhirnya subjek hamil di usia 16 tahun. Subjek kemudian menikah dengan pacarnya di usia 17 tahun dalam keadaan hamil besar dan selanjutnya tinggal bersama mertuanya. 
Saat menyadari bahwa subjek telah hamil, subjek sempat terkejut dan mengalami kebingungan karena merasa tidak siap menjadi orang tua, namun, subjek tidak berfikir sedikitpun untuk menggugurkan kandungannya. Subjek memahami bahwa anak dalam kandungannya tidak bersalah dan merupakan tanggung jawabnya, sehingga sejak awal kehamilannya bertekat untuk membesarkan anaknya meskipun semisal pacarnya tidak bertanggung jawab.

Subjek cukup senang karena pacarnya menikahinya, walaupun selama subjek hamil, suaminya mengalami perubahan sikap. Suami menjadi kasar atau main tangan, selama subjek hamil suami seringkali memukulnya atau berkata kasar. Suami jarang pulang ke rumah, dan jika pulang tidak membawa uang sedikit pun, justru pulang dalam keadaan mabuk. Keadaan ini cukup berat bagi subjek mengingat kebutuhan finansialnya semakin tinggi padahal subjek tidak dapat bekerja karena komplikasi kehamilannya. Tahap ini merupakan masa paling menderita akibat kehamilan yang tidak dikehendaki. Suami menunjukkan perilaku yang mengarah pada kekerasan yaitu berupa kekerasan fisik dan penelantaran, meskipun suami menunjukkan itikad baik tidak menghendaki adanya aborsi dan bersedia bertanggung jawab.

Meski dalam kondisi yang berat, subjek masih bertahan terhadap keberadaan suaminya karena berharap suaminya akan berubah setelah memiliki anak anak nanti. Hal ini seperti yang disampaikan Venny (2003) dimana kecenderungan korban kekerasan tetap bertahan pada kondisinya dikarenakan perempuan berharap pada suatu hari nanti pacaranya akan berubah dan perempuan juga mempersepsi bahwa kekerasan akan lenyap apabila sudah memiliki anak. Keadaan ini yang seringkali menyebabkan perempuan sulit keluar dari lingkaran kekerasan. Segaf, Yumpi, dan Kursistin (2009) dalam penelitiannya menyebutkan bahwa beberapa factor yang mendorong perempuan bertahan pada kekerasan antara lain ketidakberdayaan, afeksi yang membelenggu, penerimaan terhadap peran otoritas, harapan terhadap figure pelindung, keterbatasan memahami masalah, keterbatasan keahlian, dan kurangnya pemahaman mengenai kekerasan domestic.

Sampai mendekati proses persalinan, subjek mendapat dukungan dari bapaknya. Bahkan sampai proses persalinan bapaknya lah yang mengantar ke puskesmas dan membantu mempersiapkan segala sesuatunya. Suami dan keluarga sebenarnya mulai menunjukkan perhatiannya setelah anaknya lahir. Hari demi hari, mertua dan suami semakin sayang kepada anaknya. Perilaku buruk suami mabuk-mabukan dan melakukan kekerasan juga sudah ditinggalkan. Kondisi ini yang menyebabkan subjek mampu melewati masa-masa sulit. Dukungan akan dirasakan sangat berharga ketika seseorang berada dalam kondisi yang tidak menyenangkan (Crumbaugh dalam Bastman, 1996). Subjek yang mendapat dukungan sosial seperti merasa diperhatikan, dihargai, dan dicintai yang selanjutnya akan merasakan kepuasan dalam hidup dan dapat menghadapi tantangan dan masalah-masalahnya dengan lebih efektif.

Keberadaan anak tampaknya mampu merubah kehidupan subjek dan suaminya. Jika suaminya menjadi pribadi yang lebih positif dan bertanggung jawab, begitu pula subjek. Suami subjek memutuskan berhenti hidup di jalan, dan bekerja sebagai buruh bangunan. Meskipun penghasilannya tidak banyak, namun penghasilannya lebih stabil dan resiko kerjanya lebih rendah dibandingkan ketika hidup di jalan, namun mertua dan adik-adik iparnya masih bekerja di jalan. Pada proses ini subjek menemukan kebermaknaan hidupnya dimana subjek memiliki penghayatan hidup yang penuh makna yang membuat individu merasakan hidupnya lebih bahagia, lebih berharga, dan memiliki tujuan yang mulia untuk dipenuhinya (Frankl dalam Bastaman, 2007). 
Subjeklah yang sangat merasakan perubahan positif setelah memiliki anak. Subjek merasa sangat bersyukur atas kehadiran anaknya. Subjek yang selama ini mengalami kebingungan mengenai masa depan, saat ini sudah memiliki harapan. Ingin melihat anak tumbuh dengan sehat dan menjadi orang yang baik. Hal ini yang membuat subjek lebih bersemangat dalam menghadapi hidup. Anak adalah prioritas utama subjek saat ini. Letih dan lelah dalam mengasuh anak, baginya setimpal dengan kebahagiaannya melihat senyum dan tawa ceria anak. Penemuan kebermaknaan hidup dalam hal ini berkorelasi dengan kesejahteraan subjektif. Hal ini sesuai dengan hasil penelitian Santos, Oguan, Magramo, \& Paat (2012) yang menyatakan bahwa makna hidup dan kesejahteraan subjektif memiliki hubungan yang positif. Pemahaman yang lebih baik tentang hubungan antara makna hidup dan kesejahteraan subjektif memiliki implikasi untuk mengembangkan rasa yang lebih besar dari kebahagiaan dan kepuasan dalam hidup. Hal ini dapat dikembangkan dengan mengetuk sumber emosional untuk mengurangi kondisi afektif negatif dan mengoptimalkan situasi kehidupan yang bermakna.

Sebagai ibu, subjek cukup terampil dan sabar dalam mengasuh anak. Subjek juga rajin mengajak anak ke posyandu untuk melihat tumbuh kembang anaknya. Subjek juga saat ini mengurangi aktifitasnya di jalan. Jika dulu subjek bekerja di jalan dari pagi hingga sore, saat ini subjek hanya bekerja di sore hari saja. Hal ini tetap harus dilakukannya karena kebutuhan makan masih mengandalkan penghasilannya. Sedangkan gaji suaminya digunakan untuk keperluan lain seperti mengontrak rumah dan membeli perabot. Perubahan dalam diri subjek terjadi setelah muncul kesadaran diri akan nilai-nilai berharga yang sangat penting dalam hidupnya yang merupakan tahap penemuan makna diri. (Lubis dan Priyanti, 2009)

Subjek sebenarnya memahami kehidupan di jalanan berbahaya bagi anaknya. Untuk itu, subjek berkeinginan untuk bekerja jika anaknya sudah dapat diajak untuk bekerja yang lebih layak. Namun keinginan ini belum berhasil dilakukan karena kurangnya niat dan kondisi yang dianggap belum memungkinkan.

\section{Subjek 2}

Subjek berusia 16 tahun dan merupakan anak bungsu dari lima bersaudara. kakak-kakak subjek sudah berkeluarga sehingga subjek tinggal bersama ibunya di Kandang macan. Bapaknya sudah meninggal dunia saat subjek usia 10 tahun. Riwayat keluarga subjek sebenarnya cukup rumit. Subjek tidak mengerti betul siapa sebenarnya bapak kandungnya. Subjek mengaku memiliki dua bapak. Ibunya bercerai dan kemudian menikah lagi, dan kehadiran subjek di dunia saat ibunya sudah bercerai. Subjek juga tidak tahu siapa sebenarnya bapak kandungnya. Namun subjek tidak ambil pusing, subjek justru senang karena memiliki dua bapak.

Awal mula subjek di jalan di karenakan subjek mengenal teman-teman yang sering ngamen di malioboro dan alun-alun utara. Saat itu subjek tidak mengamen tetapi subjek sering menghabiskan waktu nongkrong bersama teman-temannya. Sampai suatu ketika subjek berhenti sekolah dikarenakan malu dengan teman-temannya diejek karena bergaul dengan anak jalanan. Subjekpun memutuskan memilih berhenti sekolah meskipun dimarahi oleh ibunya.

Sejak saat itu, subjek sering pergi dari rumah karena sering cek cok dengan ibunnya. Subjek kemudian ikut tidur di jalanan dengan teman-temannya. Sampai subjek bertemu dengan pacarnya pertamanya, salah seorang anak jalanan yang kemudian menjadi pacarnya. Kehidupan subjek selanjutnya selayaknya teman-teman 
komunitasnya. Subjek mulai merokok, minum minuman beralkohol, obat-obatan terlarang, termasuk mengenal kehidupan free sex. Setiap malam subjek tidur bersama pacarnya dengan meminjam tikar dan gerobak di alun-alun utara. Teman-temannya juga melakukan hal yang sama, setiap malam tidur berpasang-pasangan.

Subjek kemudian kembali pulang untuk merawat ibunya sampai akhirnya ibunya meninggal dunia. Ibunya memang memiliki tumor ganas. Subjek sempat pulang ke daerahnya ketika ibunya meninggal, namun subjek tidak betah hidup di desa meskipun ada bulik yang merawatnya. Subjek pun kembali ke jogja dan hidup di jalan, namun saat kembali ke jalan, subjek menemui pacarnya sudah selingkuh dengan sahabatnya. Subjek pun sangat merasa terpukul.

Sampai suatu ketika subjek mengenal pacarnya yang bernama Pandi, dikenalkan oleh kakaknya. Pandi bukan anak jalanan, tinggal di kampung. Subjek akhirnya memutuskan untuk mengakhiri hubungan dengan Tiso dan berpacaran dengan pandi. Selama berpacaran, subjek tinggal di rumah Pandi bersama orang tuanya. Sampai akhirnya subjek mengetahui dirinya hamil 4 bulan.

Subjek terkejut dan bingung dengan kehamilannya. Pandi saat diberitahu mengenai kehamilan subjek hanya tersenyum. Namun keluarga subjek maupun keluarga pandi tidak ada yang marah. Keluarga Pandi berniat untuk menikahi subjek, namun subjek belum cukup umur untuk menikah, sehingga subjek menunda pernikahannya hingga usia 17 nanti.

Subjek mampu menerima kehadiran anaknya di usia subjek 15 tahun. Subjek bahkan rajin memeriksakan kandungannya ke puskesmas, rajin mencari informasi seputar kehamilan dari membaca buku KMS maupun bertanya pada orang-orang, rajin mengikuti senam hamil, dan menyiapkan diri untuk kelahirannya.

Proses persalinan yang menguras energi dan membutuhkan pengorbanan merupakan titik balik kehidupan subjek. Subjek menyadari bahwa proses persalinan itu menyakitkan. Membesarkan anak juga bukanlah proses yang mudah. Subjek harus rela tidak tidur di malam hari untuk anaknya, subjek juga tidak lagi dapat bebas bermain bersama teman-temannya, termasuk mengurangi intensitas merokoknya setelah meiliki anak.

Keberadaan anak membuat subjek menyesal selama ini telah durhaka dengan ibunya. Subjek menyesal karena tidak menjadi anak yang baik. Dulu subjek bahkan sempat hampir membunuh ibunya dengan pisau dapur karena emosi dan sedang mabuk, untung dapat dicegah oleh kakaknya. Subjek juga menyesal karena tidak merawat ibunya dengan baik selama sakit hingga meninggal dunia. Keadaan ini merupakan tahap penemuan makna hidup yang ditandai dengan penyadaran individu akan nilai-nilai berharga yang sangat penting dalam hidupnya (Lubis \& Priyanti, 2009). Hal ini diperkuat penelitian Bhattacharya (2011) bahwasannya makna hidup seseorang sebagian dipengaruhi oleh kejadian masa lalu individu, keyakinan, harga diri, dan tanggung jawab sosial seperti yang dialami oleh subjek.

Subjek menaruh harapan yang besar terhadap anaknya. Subjek tidak ingin anaknya menjadi anak yang tidak patuh seperti dirinya. Subjek juga bertekad tidak akan membiarkan anaknya mengenal dunia jalanan yang membuatnya rusak seperti saat ini. Subjek ingin anaknya sekolah tinggi sehingga hidup lebih baik darinya. Hal ini sesuai dengan penelitian Baumeister, Vohs, Aaker, \& Gabinsky (2013) yang menunjukkan bahwa kebermaknaan hidup mengintegrasikan masa lalu, sekarang, dan masa depan. Subjek mampu mengintegrasikan masa lalu dengan masa sekarang dan mampu merancang masa depan. 
Sebagai seorang ibu, subjek cukup terampil dalam mengurus anak. Subjek bertekad memberikan asi eksklusif agar anaknya tumbuh sehat. Subjek juga rajin mengajak anaknya untuk imunisasi sesuai jadwal. Subjek tidak peduli dengan statusnya yang belum menikah. Baginya Pandi menafkahinya dan anaknya dapat tumbuh sehat sudah cukup baginya. Hal ini menunjukkan bahwa subjek berada pada tahap realisasi makna dalam kebermaknaan hidup dimana subjek mengalami semangat dan gairah dalam hidupnya, kemudian secara sadar melakukan keikatan diri (self commitment) untuk melakukan berbagai kegiatan nyata yang lebih terarah guna memenuhi makna hidupnya. (Lubis dan Priyanti, 2009)

\section{Simpulan}

Dari data dan informasi yang peneliti peroleh, dapat ditarik kesimpulan mengenai kebermaknaan hidup anak jalanan. Subjek pertama bahwa kebermaknaan hidup subjek pertama didapatkannya setelah memiliki anak. Subjek menjadi lebih bersemangat dalam hidup karena memiliki harapan untuk dapat melihat anaknya tumbuh dengan baik. Subjek juga merasa hidupnya lebih baik setelah memilki anak, termasuk menjadi pribadi yang lebih dewasa. Subjek kedua bahwa kebermaknaan hidup subjek kedua didapatkannya saat proses persalinan. Perjuangan proses persalinan yang berat dan juga perjuangan dalam mengurus anak membuatnya menyesal karena subjek tidak dapat menjadi anak yang baik sampai ibunya meninggal dunia. Keinginan yang kuat agar anaknya menjadi anak yang baik dan patuh kepada orang tua, menjadikannya pribadi yang lebih baik.

\section{Daftar Pustaka}

Alaggia,R. (2004). Many way of telling: Expanding conceptualizations of child sexual abuse disclosure. Child Abuse \& Neglect, 28, 1213-1227.

Ancok,D. 2006. Logoterapi terapi psikologi melalui pemaknaan eksistensi. Edisi 2. Yogyakarta: Kreasi Wacana Yogyakarta.

Anggriany,N. (2006). Motif sosial dan kebermaknaan hidup remaja pagalaram. Psikologika, 11, 51-63.

Bastaman,H.D. (2007). Logoterapi: Psikologi untuk menemukan makna hidup dan meraih hidup bermakna. Jakarta: PT Raja Grafindo Persada.

Baumeister,R.F.,Vohs,K.D., Aaker, J.L., \& Gabinsky, E.N. (2013). Some key differences between a happy life and meaningful life. Journal of Positive Psychology, 1-16.

Bhattacharya, A. (2011). Meaning in life: A qualitative inquiry into the life of young adults. Psychoogical Studies, 56 (3), 280-288.

Ferrara, F.F. (2002). Childhood sexual abuse: Developmental effects across the lifespan Brooks/Cole Thomson Learning, Inc Boston. 
Hurlock, E.B. (2005). Perkembangan anak. Jakarta: Erlangga.

Komisi Nasional Perempuan. (2010). Kekerasan seksual: Kenali dan tangani. Diakses dari www.komnasperempuan.or.id

Little, L., \& Hamby, S.L., (1999). Gender differences in sexual abuse outcames and recovery experience: A survey of therapist-survivors. Professional Psychology, Research and Practice, 30 (4,) 378-385.

Lubis, N.L. \& Priyanti, D. (2009). Makna hidup pada penderita kanker leher rahim. Majalah Kedokteran Nusantara, 42, 14-19.

Moleong, L.J. (2011). Metode penelitian kualitatif. Bandung: PT Remaja Rosdakarya.

Paolucci, E.O., Genuis, M.L., \& Violato, C. (2001). A meta analysis of the published research on the effects of child sexual abuse. The Journal of Psychology, 135, (1), 17-36.

Poerwandari, K. (2009). Pendekatan kualitatif untuk penelitian perilaku manusia. Jakarta: LPSP3 Universitas Indonesia.

Rathi, N. \& Rastogi, R. (2007). Meaning in life and psychological well being in pre adolescent and adolescent. Journal of the Indian Academy of Applied Psychology, 33, 31-38.

Rew, L., Johnson, R.J., \& Kauzekanani, K. (2006). Gender differences in victimized homeless adolescents. Journal Adolescence, 41, 39-46.

Santos, M.C.J., Oguan, F,J. Magramo, C.J. Paat, J.J (2012). Meaning in life and subjective well-being: Is satisfying life meaningful?. Journal of Arts, Science, and Commerce. 3, 32-40.

Segaf. Z, Yumpi. F, Kursistin,. P. (2009). Memahami alasan perempuan bertahan dalam kekerasan domestic. INSIGHT, 5 (1): 1-7.

Schultz, D. (1991). Psikologi pertumbuhan: Model-model kepribadian sehat. Terjemahan. Yogyakarta: Penerbit Kanisius.

Sorenson, S.B. (1997). Violence and sexual abuse at home: Current issues in spousal battering and child maltreatment. New York: Haworth Press.

Stegar, M.F., Kashdan, T.B., Sullivan, B.A., \& Lorentz, D. (2008). Understanding the search for meaning in life: Personality, cognitive style, and the dynamic between seeking and experiencing meaning. Journal of Personality, 76 (2), 199-226.

Triantoro, S. (2008). Perbedaan tingkat kebermaknaan hidup antara kelompok pengguna napza dengan kelompok non pengguna napza. Jurnal Humanitas, 5, 67-79.

Triono, G. (2007). Tatasane teko, kisah perkosaan dan traficking anak. Jurnal Perempuan, 55, 19-28.

Venny, A. (2003). Memahami kekerasan terhadap perempuan. Jakarta: Yayasan Jurnal Perempuan.

Yantzi, M. (2009). Kekerasan seksual \& pemulihan: Pemulihan bagi korban, pelaku, dan masyarakat. Jakarta: BPK Gunung Mulia. 